\title{
Expression of VINV1, SCB1 and SCS1 genes in the seed coats of contrasting soybean seeds ${ }^{1}$
}

\author{
Expressão dos genes VINV1, SCB1 e SCS1 em tegumentos de sementes de soja \\ contrastantes
}

\author{
Carlos André Bahry* e Paulo Dejalma Zimmer³
}

\begin{abstract}
The seed coat is vital for the proper development of soybean seeds and also, after their physiological maturity, for providing protection against various biotic and abiotic factors. The aim of this work was to evaluate the relative expression of three candidate genes, VINV1, SCB1 and SCS1, which are possibly involved in seed quality, in the contrasting seed coats of four soybean genotypes. Two yellow seed coat genotypes, BMX Potência RR and CD 202, and two black seed coat genotypes, TP and IAC, were used. Relative gene expression was evaluated by the qPCR technique for seven phases of seed coat development in the four genotypes, at 25, 30, 35, 40, 45, 50 and 55 days after anthesis. The design was completely randomised, with three replications. Data were subjected to variance analysis and the means were compared by Tukey test at 5\% probability. The VINV1 and SCS1 genes exhibit greater expression in the early stages of seed coat development in the cultivar BMX Potência RR. The SCB1 gene displays greater expression in the cultivar CD 202, also in the early stages of seed coat development. The three genes under study show greater expression in yellow seed coat genotypes.
\end{abstract}

Key words: Soybean. Coats. Candidate genes.

\begin{abstract}
RESUMO - O tegumento é vital para o adequado desenvolvimento das sementes de soja e, também, após a maturidade fisiológica destas, conferindo proteção contra os fatores bióticos e abióticos. O objetivo do trabalho foi avaliar a expressão relativa de três genes candidatos, VINV1, SCB1 e SCS1, possivelmente envolvidos com a qualidade das sementes, em tegumentos contrastantes de quatro genótipos de soja. Foram utilizados dois genótipos de tegumentos amarelos, BMX Potência RR e CD 202, e dois genótipos de tegumentos pretos, TP e IAC. A expressão relativa dos genes foi avaliada pela técnica qPCR, em sete fases de desenvolvimento dos tegumentos dos quatro genótipos, aos 25; 30; 35; 40; $45 ; 50$ e 55 dias após a antese. O delineamento foi o inteiramente casualizado, com três repetições. Os dados foram submetidos à análise de variância e as médias comparadas pelo teste de Tukey, ao nível de 5\% de probabilidade. Os genes VINV1 e SCS1 apresentam maior expressão nas fases iniciais de desenvolvimento dos tegumentos da cultivar BMX Potência RR. O gene SCB1 apresenta maior expressão na cultivar CD 202, também nas fases iniciais de desenvolvimento dos tegumentos. Os três genes estudados têm maior expressão nos genótipos de tegumentos amarelos.
\end{abstract}

Palavras-chave: Soja. Tegumentos. Genes candidatos.

\footnotetext{
*Autor para correspondência

${ }^{1}$ Recebido para publicação em 21/02/2014; aprovado em 24/10/2014

Pesquisa relacionada à Tese de Doutorado do primeiro autor, com auxílio da FAPERGS, CNPq e CAPES

${ }^{2}$ Departamento de Ciências Agrárias, Universidade Tecnológica Federal do Paraná, Pato Branco-PR, Brasil, carlosbahry@utfpr.edu.br

${ }^{3}$ Departamento de Fitotecnia, Universidade Federal de Pelotas, Pelotas-RS, Brasil, dejalma@msn.com
} 


\section{INTRODUCTION}

Seeds have been the object of study for many years due to their importance as a means of dissemination of many plant species, being therefore of interest to society. These attributes, intrinsic to seeds, are due to their ability to distribute germination over space and time (CARVALHO; NAKAGAWA, 2012).

One of the structures responsible for ensuring such autonomy to the seed is the seed coat. This acts as a modulator of the interactions between the inner parts of the seed and the external environment, preserving its integrity against biotic and abiotic factors that could compromise the metabolism as well as controlling the process of seed germination and dormancy (MOÏSE et al., 2005). The seed coat also plays a special role in seed formation, coordinating the development of the embryo (WEBER; BORISJUK; WOBUS, 2005).

Although some essential functions carried out by the seed coat are known, together with their chemical composition and morphological features (MA et al., 2004; MERTZ et al., 2009), genetic and molecular research into this structure in soybean seeds has only recently been increasing (BATCHELOR et al., 2000; BATCHELOR et al., 2002; CHO; JONES; VODKIN, 2013; MOÏSE et al., 2005). Also, when seeking information on research related to gene expression in contrasting genotypes for seed coat characteristics, the literature tends to be even more limited.

This is probably due to the fact that research is focused on soybean genotypes with seed coat characteristics similar to those of cultivars of a yellow colouration currently being used, and seeks to find superior constitutions among elite genotypes to facilitate the process of genetic improvement and reduce variability, with emphasis given to the time required to launch a new cultivar.

This work sought to study the relative expression of three genes possibly related to seed quality, VINV1, SCB1 and SCS1, using the technique of qPCR, in four contrasting genotypes for seed coat characteristics, two of yellow seed coats, CD 202 and BMX Potência RR and two of black, TP and IAC, with a view to identifying superior constitutions that could be used in further studies.

\section{MATERIAL AND METHODS}

The experiment first consisted of the multiplication of soybean seeds in a greenhouse of the Lowlands Experimental Station of Embrapa Clima Temperado, in the town of Capão do Leão, in the state of Rio Grande do Sul, Brazil (RS), during the 2012/2013 season. Four soybean genotypes contrasting for seed coat characteristics were used, the cultivars CD 202 (conventional) and BMX Potência RR (transgenic), both with yellow seed coats, and the TP and IAC genotypes, both having black seed coats.

Marking the flowers took place from anthesis, so that all the sampled seeds were at the same stage of development. For each genotype, seven collections of the pods were made at intervals of five days $(25,30,35,40,45,50$ and 55 days after anthesis).

Immediately after collection, the seed coats were separated from the seeds at the Laboratory of Seeds and Biotechnology of the Federal University of Pelotas using sterile blades. The seed coats of each genotype were then stored in an ultra-low freezer at $-80^{\circ} \mathrm{C}$ until the RNA was obtained.

The ribonucleic acid (RNA) was extracted at one time for all the treatments (genotypes and seed coat collecting times) using the Concert Plant RNA Reagent (Invitrogen ${ }^{\mathrm{TM}}$ ). After extraction, the RNA samples were treated with DNase and their purity and integrity were measured by absorbance analysis (260/280 nm) and electrophoresis in 1\% agarose gel. The RNA extraction and synthesis of complementary deoxyribonucleic acid (cDNA) was carried out using three biological replicates, with each replicate consisting of a mixture of seed coats at each stage under evaluation.

Single-stranded cDNAs were synthesised by reverse transcription from the RNA using the enzyme III SuperScript III ${ }^{\circledR}$ (Invitrogen ${ }^{\mathrm{TM}}$ ), according to the manufacturer's recommendations. To analyse the quality of the cDNA, a semi-quantitative PCR (polymerase chain reaction) was carried out using Go Taq Master mix, cDNA from each sample, water and oligonucleotides for B-actin. The purity and integrity of the cDNA were also measured in order to ensure the quality of the material used.

The selection of target genes for the study was based on both the extensive review of seed and seed coat formation carried out by Moïse et al. (2005) and also the work done by Mertz et al. (2010).

Five normalising genes were tested on a preliminary basis, ACT11, SKIP16, UKN1, UKN2 and $\beta$ ACTIN. In order to evaluate their stability, eight random samples of cDNA were used. The normalisers ACT11 and SKIP16 were chosen as they displayed less variation in expression.

To design the primers, a search was made with the database of the National Centre for Biotechnology Information (NCBI) for the EST (Expressed Sequence Tag) sequences of the proteins which correspond to the genes listed in Table 1. The primers were designed with the aid of the Vector NTI Advance 11.0 (INVITROGEN ${ }^{\mathrm{TM}}$ ) software, observing the following parameters: annealing temperature, primer size, percentage of GC (40-60\%), amplicon size and the absence of dimerisation and of secondary annealing sites. 
Table 1 - List of candidate genes, accessions and primer sequences used for qPCR

\begin{tabular}{lccc}
\hline Gene & Accession & & Primer sequence \\
\hline \multirow{2}{*}{ VINV1 } & XM_003550543.1 & Ss* & 5' TGGGTCAATGTGCTAGGCCACTGAA 3' \\
& As & 5' TGCTTGCAGGTTGCTGTGACCAAA 3' \\
\hline \multirow{2}{*}{ SCB1 } & AF467554.1 & Ss & 5' GTTGATGACAGCCAATGCTGCGTT 3' \\
& & As & 5' GATTGCTTTCGGCAAGGGAGTTCTT 3' \\
\hline \multirow{2}{*}{ SCS1 } & NM_001251323 & Ss & 5' TTCTCTGGGTTCGCAGCTCGTCTAT 3' \\
& & As & 5' GAGCTTCAGAATGGGGTCAGGGAA 3' \\
\hline
\end{tabular}

*Ss: sense; AS: antisense

After relative quantification, the quality of the amplified product was verified from the dissociation curves at the end of the qPCR from the gradual increase in the reaction temperature. Calculation for fluorescence emission then followed, evaluating the analytical specificity of the primers using the denaturation of the generated PCR product.

Serial dilutions of $1: 3 ; 1: 30 ; 1: 300 ; 1: 3000$ were carried out to obtain the Slope and calculate the efficiency of each gene, using Formula 1 (ZHAO; FERNALD, 2005) (Table 2):

$\mathrm{E}=\left|10^{(-1 / \text { slope })}\right|-1$

Real time quantitative analysis of gene expression in the target genes was carried out with a Light Cycler 480 Instrument II (96) (Roche Applied Science®) using SYBR $®$ Green. At the end of the reaction tests the $\mathrm{Cp}$ (Crossing point) was obtained. The relative expression of the three candidate genes was calculated based on the amplification efficiency (E) and the PCR cycle for which an increase in fluorescence above the baseline (Cp) was detected (PFAFFL, 2001).

The gene expression values were normalised using the values observed at 25 days after anthesis for the BMX Potência RR genotype, and the results submitted to variance analysis and then compared by means test employing Tukey at 5\% probability.

Table 2 - Slope value and amplification efficiency of the primers

\begin{tabular}{lcc}
\hline \multicolumn{1}{c}{ Gene } & Slope $(\mathrm{S})$ & Efficiency $(\mathrm{E})$ \\
\hline VINV1 & $-3.355^{1}$ & 0.98638 \\
SCB1 & -3.615 & 0.89071 \\
SCS1 & -3.572 & 0.90526 \\
\hline
\end{tabular}

${ }^{1}$ Acceptable standards for a Slope of -3.2 according to Applied Biosystems ${ }^{\circledR}$

\section{RESULTS AND DISCUSSION}

The variance analysis indicated interaction between contrasting genotypes and stages of development of the soybean seed coats (days after anthesis) for the three candidate genes being evaluated (Table 3). In this way, the average expression data were compared between the genotypes for each stage of seed coat development, and between the stages of development for each genotype.

The VINV1 enzyme is an invertase which catalyses the cleavage of sucrose into glucose and fructose, and is present at various sites in plants, including the cell wall, vacuoles and cytoplasm (PATRICK; BOTHA; ANDBIRCH, 2013; VARGAS, SALERNO, 2010, WEBER et al., 1995).

With respect to invertase expression in contrasting soybean seed coats, it was possible to find differences between genotypes, and also between the seed coat development stages.

The relative expression of the VINV1 gene at 25 and 45 days after anthesis (DAA) was greater for the BMX Potência RR genotype in relation to the other genotypes. Whereas at 30, 35, 40 and 55 DAA, there was greater expression of the corresponding gene in the black seed coat TP genotype, however, with no difference at 35 and 55 DAA from the BMX Potência RR genotype, or the IAC genotype at 55 DAA. At 50 DAA expression was greater in the CD 202 genotype, followed by both BMX Potência RR and IAC, which did not differ.

The VINV1 gene is homologous to the invertase studied by Weber et al. (1995) in Vicia faba. According to those authors, this contributed to the transformation of sucrose into hexoses, principally in the pre-storage phase. A greater expression of the VfVINV1 gene is therefore to be understood for the initial stages of seed development, when they are in full cell division.

Invertases are also involved in the maturation of fruit, and possibly regulate the levels of hexoses in mature 
tissues and the mobilisation of sucrose stored in the vacuoles. Therefore, the variable levels of expression observed at some of the stages of seed coat development for some genotypes can be properly explained (ELLIOTT et al., 1993).

In the BMX Potência RR genotype, the results for the expression of the VINV1 gene were higher at 25 DAA (days after anthesis). Whereas the lowest values for the expression of the gene for the respective genotype were found at 30 to $50 \mathrm{DAA}$, with in this case, a greater expression pattern being seen at the start of seed coat development.

There is a correlation between the growth of the embryo within the limits of the pod and the crushing of the internal cell layers of the seed coat. This compression therefore compromises the correct development of the cell walls of the seed coat, one of the sites of invertase synthesis, so affecting their complete functioning and thus stopping growth of the embryo (WEBER et al., 1995). As a result, there is less expression of the respective gene, generally in the final stage of seed coat formation.

The molecular physiology of photosynthate unloading and partitioning during the development of seeds of Vicia faba (broad bean) has been studied by Weber et al. (1995). Those researchers observed that during the pre-storage phase, high levels of hexoses in the cotyledons and the apoplastic endospermal spaces correlate with the activity of invertase attached to the seed coat wall, giving it the role of mediator and driving force of the sink activity of the seeds. Additionally, these invertases act with the cell cycle, promoting the division

Table 3 - Summary of the variance analysis of the relative expression of the VNV1, SCB1 and SCS1 genes in seed coats collected at seven stages of development, for four contrasting soybean genotypes

\begin{tabular}{lcccc}
\hline \multirow{2}{*}{ SV } & \multirow{2}{*}{ DF } & \multicolumn{3}{c}{ Mean Square } \\
\cline { 3 - 5 } & & VNV1 & SCB1 & SCS1 \\
\hline Genotypes (F1) & 3 & $0.14255^{*}$ & $24.84011^{*}$ & $2.24729^{*}$ \\
Collection Times (F2) & 6 & $0.03401^{*}$ & $57.44627^{*}$ & $11.92768^{*}$ \\
F1xF2 & 18 & $0.07972^{*}$ & $16.84838^{*}$ & $1.96661^{*}$ \\
Residual & 28 & $0.00046^{*}$ & $0.26534^{*}$ & $0.05108^{*}$ \\
CV $(\%)$ & & 10.51 & 24.85 & 22.52 \\
\hline
\end{tabular}

SV - Sources of variation; DF - Degrees of freedom; *significant at $5 \%$ probability

Figure 1 - Relative expression of the VINV1 gene in seed coats collected after anthesis at seven stages of development, for four soybean genotypes contrasting for seed coat characteristics

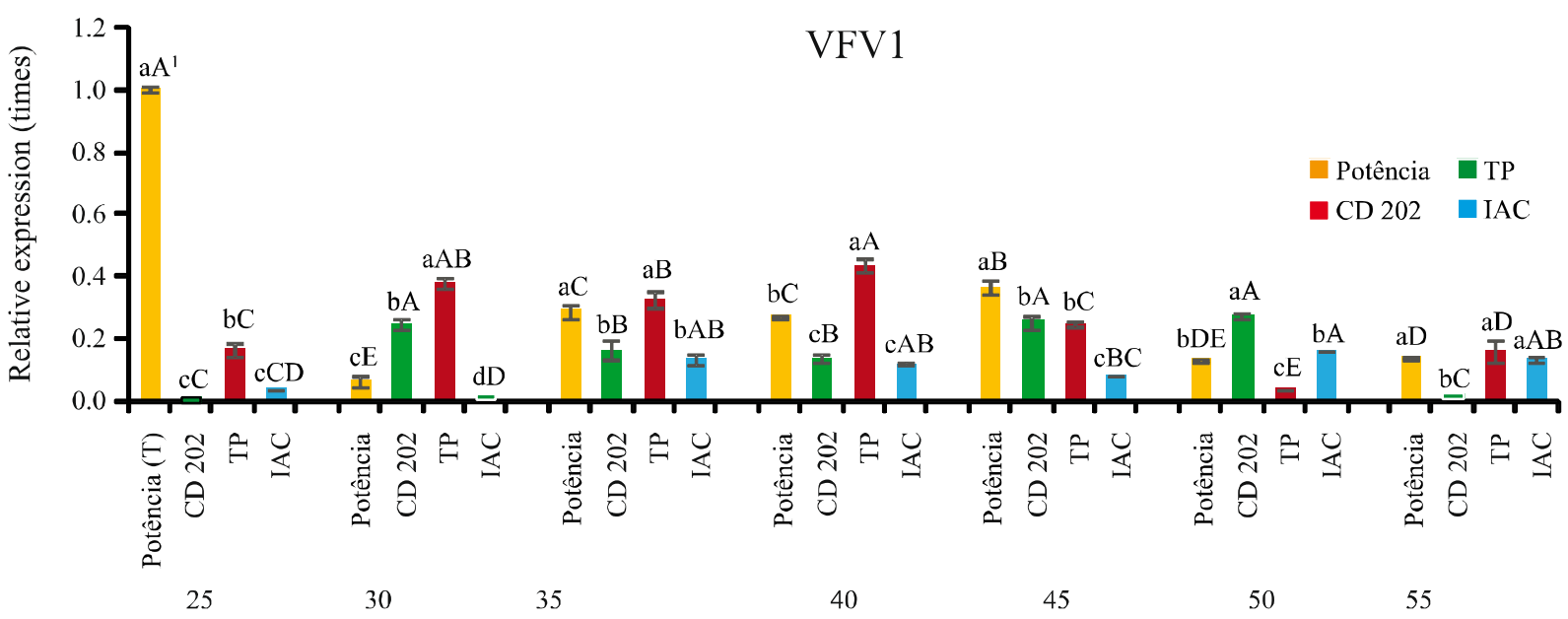

Days after anthesis

${ }^{1}$ Averages followed by different letters, lowercase between genotypes for each collection time and uppercase for each genotype and between collection times, differ by Tukey test at $5 \%$ probability 
and expansion of the cells (BIHMININE et al., 2013; CHOPRA; KAUR; GUPTA, 2005).

In relation to the $\mathrm{CD} 202$ genotype, the greatest gene expression was seen at 30, 40 and 45 DAA. For the TP genotype, greatest gene expression took place at 30 and 40 DAA, the former period not differing from 35 DAA. Whereas the lowest gene expression for this genotype was at 50 DAA.

For the black seed coat IAC genotype, the greatest gene expression pattern was seen more towards the end of seed coat development, i.e. at 50 DAA, however without differing from the expression seen at 35, 40 and 55 DAA. In the specific case of this genotype, lowest expression occurred in the initial stage of seed coat development, i.e. at 30 DAA, not differing from that at 25 DAA.

The SCB1 gene belongs to a large family, present in plant organisms that present a BURP domain, but with functions which are not very well understood to date (GAN et al., 2011). Some evidence however, points to the role of these genes in the accumulation of storage proteins (TEERAWANICHPAN et al., 2009).

Seventeen genes with a BURP domain have been identified and analysed by Ding et al. (2009). According to researchers, most of these genes displayed differential expressions when plants were subjected to abiotic stresses, such as water shortage, low temperature, salinity and supply of abscisic acid. Similar observations were made by Shao et al. (2011) for Populus trichocarpa.

In the case of the soybean, specifically in the seed coats, Batchelor et al. (2002) also identified a protein having a BURP domain, the SCB1 which is investigated in this study.

The greatest expression of the SCB01 gene, at 25 days after anthesis (DAA), was seen in the CD 202 genotype, being significantly higher than in the others, which showed no differences between themselves. A similar situation was seen at 30 DAA, when the gene expression for that genotype was greatest, however with greater expression also being observed in the BMX Potência RR and IAC genotypes, which also did not differ between themselves; a lower expression was observed for the PD genotype (Figure 2). Starting at 35 DAA, expression of the SCB1 gene was lowered for all genotypes, with no differences seen between them.

According to Batchelor et al. (2002), the SCB1 protein (Seed Coat BURP domain protein 1) is specifically expressed in the seed coat of soybean seeds at the beginning of their development. The mRNA of the gene first accumulates in the inner walls of the integumentary parenchyma and later in the outer walls. This accumulation takes place before maturation of this structure and swelling of the seed. This expression pattern is due to a possible function attributed to this gene, which supposedly acts in the formation, more specifically in the differentiation, of cells in the parenchyma of the integument, and also in the allocation of proteins in the cell wall matrix.

Furthermore, the presence of intercellular spaces in the nutrient unloading zone for the embryo has shown that they arrive via the apoplastic pathway, with the SCB1 gene possibly directly involved in the process of

Figure 2 - Relative expression of the SCB1 gene in soybean seed coats collected after anthesis at seven stages of development, in four genotypes contrasting for seed coat characteristics

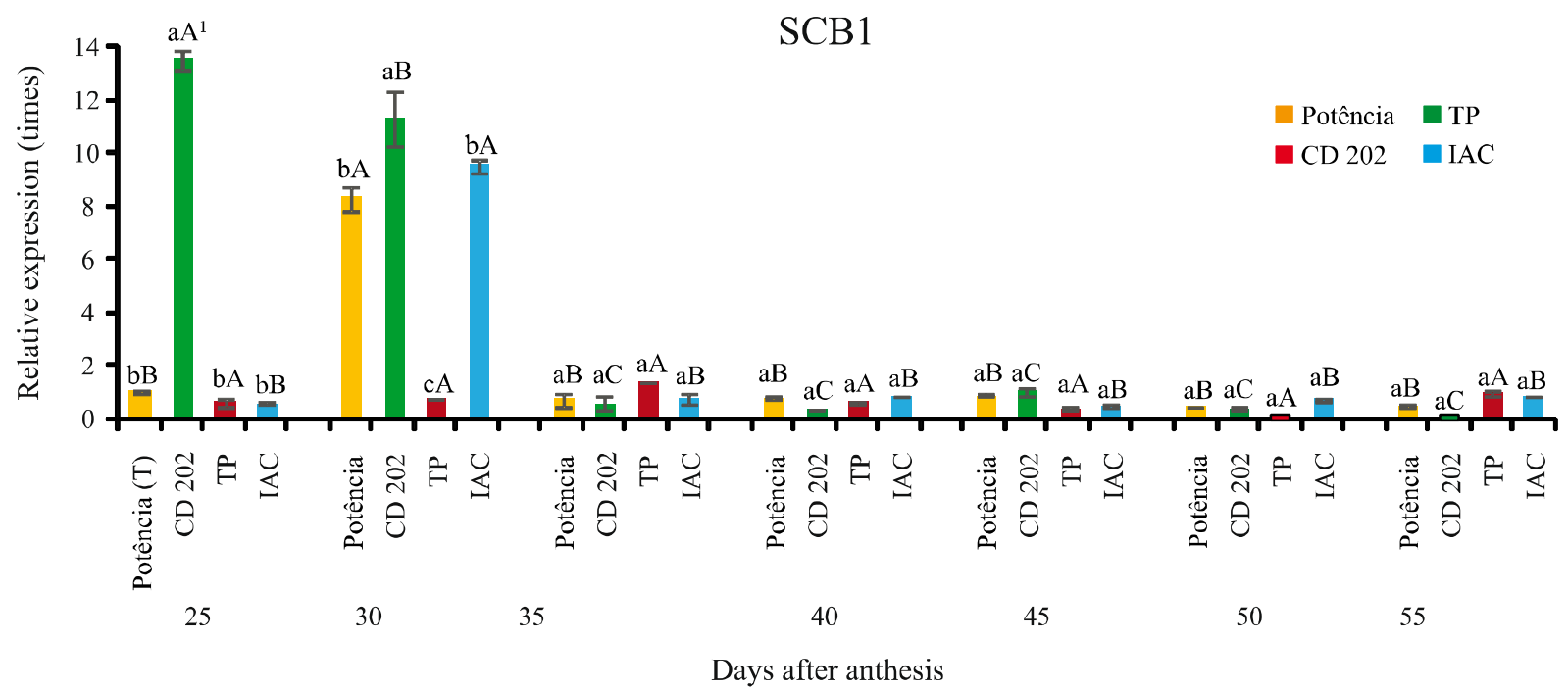

${ }^{1}$ Averages followed by different letters, lowercase between genotypes for each collection time and uppercase for each genotype and between collection times, differ by Tukey test at $5 \%$ probability 
differentiation of these cells to form structures similar to the aerenchyma (MILLER et al . 1999).

When analysing the expression of the SCB1 gene in the BMX Potência RR genotype, it could be seen that this was greatest at $30 \mathrm{DAA}$, with no difference between the remaining stages of seed coat development.

For the CD 202 genotype, the greatest expression occurred at $25 \mathrm{DAA}$, followed by $30 \mathrm{DAA}$. In relation to the other stages of seed coat development, for this genotype there was no difference in expression for the gene in question (Figure 2).

Although seeing greater expression of the SBP1 gene in the early stages of seed coat development, i.e. at 25 and 30 DAS, Batchelor et al. (2002) found a greater expression of this gene even earlier, at nine and twelve days after anthesis.

For the TP genotype no difference in expression of the gene was seen in relation to the stages of seed coat development. A similar situation was observed for IAC, with the exception of the higher expression observed at 30 DAA.

Despite the possible functions assigned to the SCB1 gene, it is still too early to state its precise function; there is a need for further research to clarify precisely what its real role is in the initial formation of both seed coat and seed in the soybean.

The SCS1 gene is a member of the subtilase superfamily. Studies have attributed to the subtilisins the function of signal peptide for plant defence, activating genes related to defence against biotic and abiotic stresses (PEARCE et al., 2010), and also playing an important role in the degradation of storage proteins during the germination process of soybean seeds (TAN-WILSON; BANDAK; PRABU-JEYABALAN, 2012).

The greatest expression of the SCS1 gene, at 25 days after anthesis (DAA), was observed for genotype CD 202, being significantly higher in relation to the other genotypes; followed by BMX Potência RR, which did not differ from the TP genotype. No differences for the TP genotype were seen in relation to the IAC genotype (Figure 3).

A different expression pattern to that above was observed prior to 30 DAA, with the highest value being found in the BMX Potência RR genotype, followed by IAC, CD 202 and TP. There were differences between all of the genotypes under study. At 35, 40 and 45 DAA, no differences were seen between genotypes for expression levels of the SCS1 gene. At 50 and 55 DAA, greater gene expression was seen in the IAC genotype, not however differing from BMX Potência RR or CD 202 at 50 DAA, and from BMX Potência RR or TP at 55 DAA.

It is evident from the data in Figure 3, that this gene has greater expression in the early stages of seed coat development in the soybean, there being a reduction in expression from 35 DAA. According to Batchelor et al. (2000), the gene in question possibly acts in the formation and differentiation of the thick parenchyma cells in the integument of the soybean seeds, seeing that the greatest

Figure 3 - Relative expression of the SCB1 gene in soybean seed coats collected after anthesis at seven stages of development, in four genotypes contrasting for seed coat characteristics

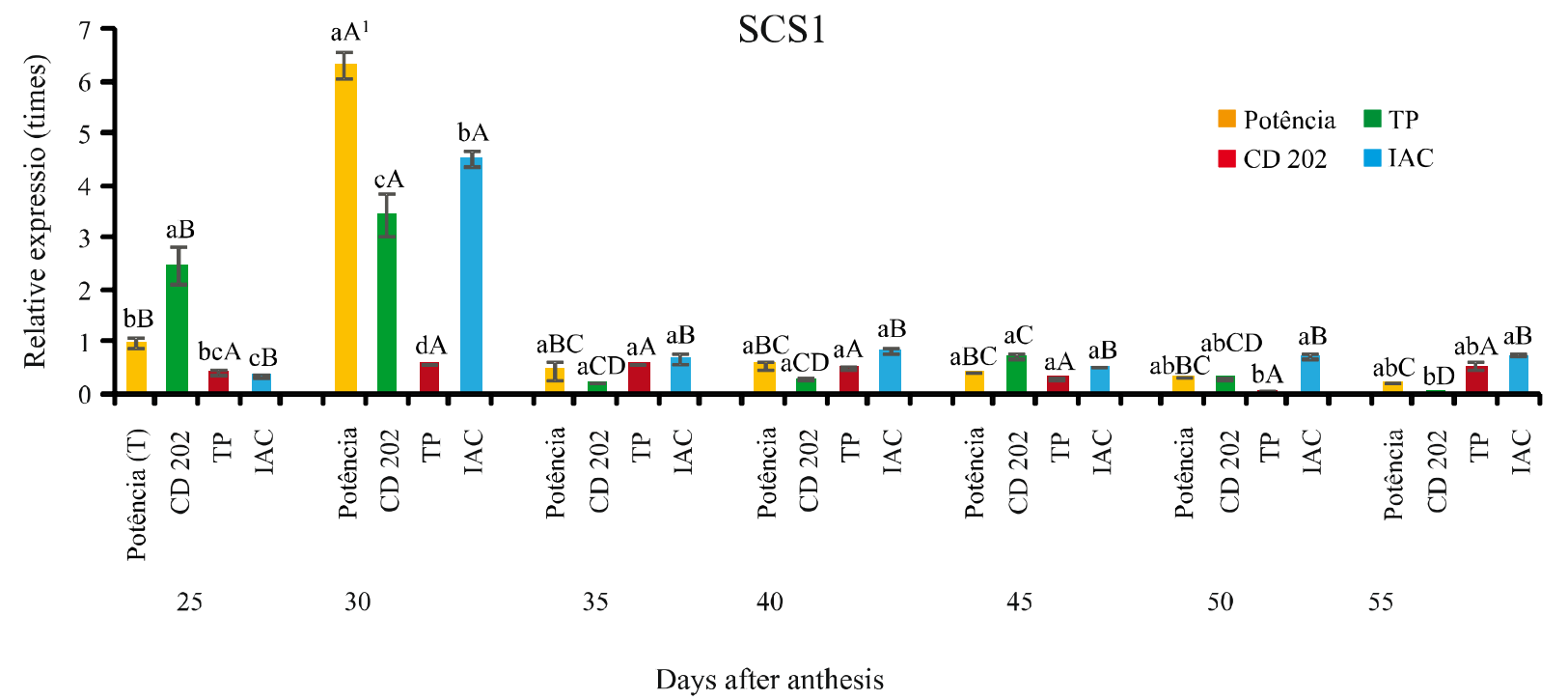

${ }^{1}$ Averages followed by different letters, lowercase between genotypes for each collection time and uppercase for each genotype and between collection times, differ by Tukey test at $5 \%$ probability 
accumulation of mRNA was noted before the maximum differentiation of this structure, more specifically at 12 DAA. This period also slightly precedes the complete extension of vascular tissue in the cover around the seed coat, and the embryo filling with protein and lipid bodies.

The thick parenchymal cells are derived from the inner seed coat, this being very prominent during the first week of formation. These cells are important in the apoplastic translocation of nutrients to the embryo. The SCS1 gene may therefore be contributing to the formation of this network of vascular tissue responsible for the nutrition of the embryo during its formation (MOÏSE et al., 2005).

The highest expression value of the SCS1 gene for the BMX Potência RR genotype was observed at 30 DAA, with there being no difference in expression at $25,35,40,45$ or 50 DAA. The lowest expression was noted at 55 DAA, however, there was no difference from 35, 40, 45 and 50 DAA (Figure 3).

In the CD 202 genotype, the greatest expression was seen at $30 \mathrm{DAA}$, followed by that at $25 \mathrm{DAA}$. The lowest expression of the SCS gene for this genotype was observed at 55 DAA, however there being no difference from 50 DAA. Despite finding greater expression of this gene in the early stages of seed coat development, Batchelor et al. (2000) saw no signs of significant expression for SCS1 from 18 to $24 \mathrm{DAA}$, the expression being zero during formation of the embryo.

The subtilisins are mainly expressed at the stages of tissue development where cell division occurs. Neuteboom et al. (1999) mention the significant expression of the AlR3 gene, also a subtilisin, during the formation of lateral roots in Arabidopsis thaliana.

Also for the same species, Rautengarten et al. (2008) found a greater expression of the subtilisin AtSBT1.7 in seeds from eight to ten days after anthesis, reinforcing the hypothesis that these genes are involved in the process of cell division in the seed coat. In addition, researchers have carried out silencing of this gene, presenting the mutations: a deformation in seed coat rupture due to non-expansion and incorrect water absorption by the layer of mucilage located below the outer layer of the seed coat which is responsible for its complete rupture. According to the researchers, these results showed that AtSBT1.7 triggers the accumulation and/or activation of enzymes which are necessary for loosening the outer primary wall of the seed coat.

Another possibility is that this gene is responsible for facilitating the increase in volume of the mucilage, thereby allowing complete disruption of the seed coat for seedling emergence associated with water absorption (RAUTENGARTEN et al., 2008).

As for the TP genotype, no differential expression was seen for the SCS1 gene between the different stages of seed coat development. Whereas for IAC, the greatest expression occurred at 30 DAA, similar to that observed in the BMX Potência RR and CD 202 genotypes. However, there was no difference in expression for the other stages (Figure 3).

The results noted for the expression of the three candidate genes allow some comments to be made. BMX Potência RR and CD 202, and especially the first, are genotypes which are widely found in cultivated areas. The latter was extensively used by farmers until a few years ago, but due to the emergence of new cultivars, has gone through a natural process of replacement by the same farmers. What both genes have in common is the process of plant breeding that has not been seen in the black coat genotypes. When it comes to grain-producing species, where the aim is greater volume produced by farmers and industry, the more space available in the seeds for the allocation of photoassimilates, generally the greater the productivity tends to be per area.

Plant breeding has therefore ended up, purposely or not, selecting materials with a higher seed mass when compared to genotypes with black seed coats, which have smaller seeds. Due to displaying such a characteristic, it is believed that the seeds from these improved genotypes should have a larger quantity of cells for the allocation of reserve substances, a process made viable by increased cell division, thereby affording the seeds greater sink capacity. Hence, the importance of the genes studied here, which may be acting in this process, and also in the nutrition of the embryo, contributing to a greater sink capacity of the seeds, and being of interest in scientific research.

\section{CONCLUSIONS}

1. The VINV1 and SCS1 genes display greater expression in the early stages of development of the seed coat in the BMX Potência RR soybean cultivar. The SCB1 gene shows greater expression in the CD 202 soybean cultivar, also in the early stages of development of the seed coat;

2. All three genes under study display a higher relative expression in yellow seed coat genotypes than in black seed coat genotypes.

\section{ACKNOWLEDGEMENTS}

The authors wish to thank CNPq, FAPERGS and CAPES for the grant of a scholarship and other financial aid.

\section{REFERENCES}

BATCHELOR, A. K. et al. SCB1, a BURP-domain protein gene from developing soybean seed coats. Planta, v. 215, n. 4, p. 523-532, 2002. 
BATCHELOR, A. K. et al. The seed coat-specific expression of a subtilisin-like gene, SCS1, from soybean. Planta, v. 211, v. 4, p. 484-492, 2000.

BIHMIDINE, S. et al. Regulation of assimilate import into sink organs: update on molecular drivers of sink strength. Frontiers in Plant Science, v. 4, n. 177, p. 1-15, 2013.

CARVALHO, N. M. de; NAKAGAWA, J. Importância da semente. In: Sementes: Ciência, Tecnologia e Produção. Funep: Jaboticabal, 2012. cap. 2, p. 6-11.

CHO, Y. B.; JONES, S. I.; VODKIN, L. The transition from primary sirnas to amplified secondary sirnas that regulate chalcone synthase during development of Glycine max seed coats. PloS One, v. 8, n. 10, p. 1-10, 2013.

CHOPRA, J.; KAUR, N.; GUPTA, A. K. Activities of sucrolytic enzymes in developing pods of lentil genotypes differing in seed size. Acta Physiologiae Plantarum, v. 27, n. 1, p. 89-93, 2005.

DING, X. et al. Genome-wide identiWcation of BURP domaincontaining genes in rice reveals a gene family with diverse structures and responses to abiotic stresses. Planta, v. 230, n. 1, p. 149-163, 2009.

ELLIOTT, K. J. et al. Isolation of fruit vacuolar invertase genes from two tomato species and temporal differences in mRNA levels during fruit ripening. Plant Molecular Biology, v. 21, n. 3, p. 515-524, 1993.

GAN, D. et al. Genome-wide analysis of BURP domaincontaining genes in Maize and Sorghum. Molecular Biology Reports, v. 38, n. 7, p. 4553-4563, 2011.

MA, E. et al. Cracks in the palisade cuticle of soybean seed coats correlate with their permeability to water. Annals of Botany, v. 94, n. 2, p. 213-228, 2004.

MERTZ, L. M. et al. cDNA-AFLP analyses between black and yellow soybean seed coats. Seed Science and Technology, v. 38, n. 1, p. 88-95, 2010.

MERTZ, L. M. et al. Diferenças estruturais entre tegumentos de sementes de soja com permeabilidade contrastante. Revista Brasileira de Sementes, v. 31, n. 1, p. 23-29, 2009.

MILLER, S. S. et al. Early development of the testa of soybean (Glycine max). Annals of Botany, v. 84, n. 3, p. 297-304, 1999.

MOÏSE, J. A. et al. Seed coats: structure, development, composition, and biotechnology. In Vitro Cellular and Developmental Biology - Plant, v. 41, n. 5, p. 620-644, 2005.
NEUTEBOOM, L. W. et al. Isolation and characterization of cDNA clones corresponding with mRNAs that accumulate during auxin-induced lateral root formation. Plant Molecular Biology, v. 39, n. 2, p. 273-287, 1999.

PATRICK, J. W.; BOTHA, F. C.; ANDBIRCH, R. G. Metabolic engineering of sugars and simple sugar derivatives in plants. Plant Biotechnology Journal, v. 11, n. 2, p. 142-156, 2013.

PEARCE, G. et al. A subtilisin-like protein from soybean contains an embedded, cryptic signal that activates defenserelated genes. Proceedings of the National Academy of Sciences of the USA, v. 107, n. 33, p. 14921-14925, 2010.

PFAFFL, M. W. A new mathematical model for relative quantification in real time RT - PRC. Nucleic Acids Research, V. 29, n. 9, p. 2003-2007, 2001.

RAUTENGARTEN, C. et al. A subtilisin-like serine protease essential for mucilage release from Arabidopsis seed coats. The Plant Journal, v. 54, n. 3, p. 466-480, 2008.

SHAO, Y. et al. Genome-wide analysis of burp domaincontaining genes in Populus trichocarpa. Journal of Integrative Plant Biology, v. 53, n. 9, p. 743-755, 2011.

TAN-WILSON, A.; BANDAK, B.; PRABU-JEYABALAN, M. The PA domain is crucial for determining optimum substrate length for soybean protease C1: Structure and kinetics correlate with molecular function. Plant Physiology and Biochemistry, v. 53, n. 9, p. 27-32, 2012.

TEERAWANICHPAN, P. et al. Protein storage vacuoles of Brassica napus zygotic embryos accumulate a BURP domain protein and perturbation of its production distorts the PSV. Plant Molecular Biology, v. 71, n. 4/5, p. 331-343, 2009.

VARGAS, W. A.; SALERNO, G. L. The Cinderella story of sucrose hydrolysis: alkaline/neutral invertases, from cyanobacteria to unforeseen roles in plant cytosol and organelles. Plant Science, v. 178, n. 1, p. 1-8, 2010.

WEBER, H.; BORISJUK, L.; WOBUS, U. Molecular physiology of legume seed development. Annual Review of Plant Biology, v. 56, n. 1, p. 253-279, 2005.

WEBER, H. et al. Seed coat-associated lnvertases of Fava bean control both unloading and storage functions: cloning of cDNAs and cell type-specific expression. The Plant Cell, v. 7, n. 11, p. 1835-1846, 1995.

ZHAO, S.; FERNALD, R. D. Comprehensive algorithm for quantitative real-time polymerase chain reaction. Journal of Computational Biology, v. 12, n. 8, p. 1047-1064, 2005. 